\title{
PENINGKATAN AKTIVITAS DAN HASIL BELAJAR BIOLOGI MELALUI PENERAPAN STRATEGI PQ4R (PREVIEW, QUESTION, READ, REFLECT, RECITE, AND REVIEW)
}

\author{
HIDAYATHUZ ZAHRA \\ Pendidikan Biologi FKIP Universitas Muhammadiyah Metro \\ E-mail: maniesssss@yahoo.co.id
}

\begin{abstract}
Students achievement in Biology Class XI IPA $A_{1}$ SMA Muhammadiyah 1 Metro is still low, in learning process students participant is low so learning process is not active. From that coundition the researcher aplly PQ4R Strategy (Preview, Question, Read, Relfect, Recite, and Review). This strategy can help students to remember in reading comprehension, asking question and answering question that given by the teacher. In this reseach is Class Room Active Reseach (CAR). This reseach is purpose to increase the activity and students result of the study of XI IPA ${ }_{1} S M A$ Muhammadiyah 1 Metro. Data of students activities in the class are: students who give attention to the teacher explanation is $87,7 \%$, reading activity is $81,5 \%$, asking question activity $21 \%$, doing an examination is $84,2 \%$, and activity make outhine is $75,4 \%$. The result study of the students in Pra-CAR in cycle II is increasing to be $24,5 \%$, on the Pra-CAR $46,5 \%$ to be $71 \%$. While the increasing of cycle I to cycle II is $58 \%$ from cycle I from $13 \%$ to be $71 \%$ to cycle II.A.
\end{abstract}

Kata kunci: PQ4R aktivitas belajar, hasil belajar

Pada jaman yang serba modern ini, pendidikan dituntut dapat mengikuti perkembangan Ilmu Pengetahuan dan Teknologi yang semakin maju. Abad mendatang merupakan suatu tantangan bagi generasi yang akan datang. Sekolah adalah salah satu pusat kegiatan belajar yang merupakan lingkungan pendidikan formal, dikatakan formal karena di sekolah terlaksana serangkaian kegiatan terencana dan terorganisasi, termasuk kegiatan dalam rangka proses belajar mengajar di kelas. Peranan sekolah dalam meningkatkan mutu pendidikan dan hasil belajar yaitu dengan melaksanakan peningkatan pembelajaran dengan baik dan menyenangkan, sehingga siswa akan lebih mudah menyerap materi pelajaran. Upaya dalam meningkatkan hasil belajar dan mutu pendidikan dengan menggunakan strategi pembelajaran yang tepat. Guru merupakan kunci dan sekaligus ujung tombak pencapaian misi pembaharuan pendidikan, mereka berada dititik sentral untuk mengatur, mengarahkan dan menciptakan suasana kegiatan pembelajaran yang untuk mencapai tujuan dan misi pendidikan.

Dari hasil prasurvei di lapangan yaitu hasil observasi di SMA Muhammadiyah 1 Metro tercatat bahwa masih banyak siswa yang tidak atau belum tuntas dalam belajar.

Siswa yang sudah tuntas belajar disebabkan karena siswa tersebut rajin, selalu mendengarkan dan mencatat apa yang guru jelaskan dan yang terpenting adalah siswa menyukai pelajaran tersebut. Sedangkan beberapa siswa yang belum tuntas belajar memiliki gejala-gejala: keterlibatan atau aktivitas siswa dalam pembelajaran masih rendah, kurangnya motivasi belajar siswa, ketidakseriusan siswa dalam mengikuti pembelajaran, sehingga siswa banyak tidak memperhatikan penjelasan guru. 
Permasalahan tersebut perlu diupayakan pemecahannya. Dari hasil observasi dan wawancara dengan guru, maka diputuskan untuk ada perubahan yang mendasar dalam proses pembelajaran seperti model atau strategi pembelajaran. Sehingga peneliti memilih startegi yang dianggap tepat untuk meningkatkan aktivitas belajar siswa yaitu strategi pembelajaran PQ4R karena dalam pelaksanaan strategi ini siswa akan lebih aktif dalam pembelajaran sehingga aktivitas memperhatikan penjelasan guru, bertanya, membaca buku, mengerjakan latihan, dan menulis intisari akan tampak pada pembelajaran ini.

Berdasarkan latar belakang masalah di atas penulis merumuskan masalah: 1) Apakah pembelajaran dengan strategi pembelajaran PQ4R dapat meningkatkan aktivitas belajar siswa kelas XI IPA 1 di SMA Muhammadiyah 1 Metro Tahun Pelajaran 2011/ 2012. 2) Apakah pembelajaran dengan strategi pembelajaran PQ4R dapat meningkatkan hasil belajar siswa kelas XI IPA ${ }_{1}$ di SMA Muhammadiyah 1 Metro Tahun Pelajaran 2011/ 2012. Tujuan penelitian ini yaitu 1) Untuk meningkatkan aktivitas belajar siswa kelas XI IPA Ii $_{1}$ SMA Muhammadiyah 1 Metro dengan menggunakan strategi pembelajaran PQ4R. 2) Untuk meningkatkan hasil belajar siswa kelas XI IPA 1 di SMA Muhammadiyah 1 Metro dengan menggunakan strategi pembelajaran PQ4R.

Dick dan Carey dalam Riyanto (2010:132) menyatakan: Strategi pembelajaran adalah semua komponen materi atau paket pengajaran dan prosedur yang digunakan untuk membantu siswa dalam mencapai tujuan pengajaran. Startegi pembelajaran tidak hanya terbatas pada prosedur kegiatan, melainkan termasuk seluruh komponen materi atau paket pengajaran dan pola pengajaran itu sendiri.

Menurut Hamalik dalam Riyanto (2010:134) "secara teknis, strategi pembelajaran adalah metode dan prosedur yang ditempuh oleh siswa dan guru dalam proses pembelajaran untuk mencapai tujuan berdasarkan materi pengajaran tertentu dan bantuan unsur penunjang tertentu pula”.

Dari pendapat di atas startegi pembelajaran merupakan suatu prosedur yang digunakan untuk membantu dalam proses pembelajaran yang didukung oleh unsur penunjang dan materi pembelajaran tertentu yang dapat mempermudah guru dan siswa dalam mencapai tujuan pembelajaran. Terdapat jenis strategi pembelajaran yaitu Strategi Pembelajaran Langsung (Direct Instruction), Strategi Pembelajaran Cooperative Learning, Strategi Pembelajaran Problem Solving, Strategi Mengulang, Strategi Elaborasi, dan Starategi Organisasi.

Trianto (2009:150) menyatakan "strategi PQ4R merupakan salah satu bagian dari strategi elaborasi. Strategi ini digunakan untuk membantu siswa mengingat apa yang mereka baca, dan dapat membantu proses belajar mengajar di kelas yang dilaksanakan dengan kegiatan membaca buku". Thomas dan Robinson dalam Trianto (2009:151) startegi PQ4R salah satu strategi yang membantu siswa dalam memahami dan mengingat materi yang mereka baca.

Menurut Al-Syihab (2010) bahwa sampai sejauh ini tidak ada satupun strategi yang dianggap paling baik, karena baik tidaknya model atau strategi yang digunakan tergantung kepada tujuan pembelajaran yang hendak dicapai. Kelebihan dan kelemahan strategi PQ4R sebagai berikut: a) Kelebihan : cocok untuk kelas besar dan kecil. Dapat dipergunakan untuk materimateri yang mengandung fakta-fakta, 
sila-sila, rukun-rukun atau prinsipprinsip dan definisi-definisi. Strategi ini mudah ketika peserta didik harus mempelajari materi yang bersifat menguji pengetahuan kognitif. Strategi ini cocok untuk memulai pembelajaran sehingga peserta didik akan terfokus perhatiannya pada istilah dan konsep yang akan dikembangkan dan yang berhubungan dengan mata pelajaran untuk kemudian dikembangkan menjadi konsep atau bagan pemikiran yang lebih ringkas. Strategi ini memungkinkan siswa belajar lebih aktif, karena memberikan kesempatan mengembangkan diri, diharapkan mampu memecahkan masalah sendiri dengan menemukan dan bekerja sendiri. b) Kelemahan: jika PQ4R digunakan sebagai strategi pembelajaran pada setiap materi pelajaran, maka guru akan sulit mengontrol kegiatan dan keberhasilan siswa. Dalam mengimplementasikannya, memerlukan waktu yang panjang sehingga guru sulit menyesuaikannya dengan waktu yang ditentukan. Menuntut para guru untuk lebih menguasai materi lebih luas lagi standar yang telah ditetapkan.

Keberhasilan suatu pembelajaran tidak dapat tercapai begitu saja tanpa adanya aktivitas belajar dari siswa tersebut, maka pembelajaran tidak akan berhasil. Aktivitas belajar merupakan proses dalam pencapaian hasil belajar. Hal tersebut sesuai dengan pendapat Sardiman dalam Arief (2008:6) yang menyatakan: dalam belajar sangat diperlukan adanya aktivitas, tanpa aktivitas belajar itu tidak mungkin akan berlangsung dengan baik. Aktivitas dalam proses belajar mengajar merupakan rangkaian kegiatan yang meliputi keaktifan siswa dalam mengikuti pelajaran, bertanya hal yang belum jelas, mencatat, mendengarkan, berpikir, membaca dan segala kegiatan yang dilakukan yang dapat menunjang prestasi belajar.

Berdasarkan kutipan di atas terlihat bahwa aktivitas belajar adalah kegiatan siswa dalam berinteraksi pada proses pembelajaran yang mengakibatkan perubahan pada dirinya. Contohnya bertanya kepada guru sehingga siswa memperoleh jawaban yang membuat siswa mengerti dan menjadi tahu apa yang tidak mereka mengerti.

Menurut Ahmadi (2001:21) mengemukakan bahwa: suatu hasil belajar yang dicapai dalam suatu usaha belajar dalam hal ini adalah mewujudkan nilai dan prestasi belajar yang dapat dilihat pada hasil atau nilai dan prsetasi belajar siswa yang diperoleh dalam setiap mengikuti tes. Hasil belajar merupakan hasil kerja yang sangat kompleks dan banyak faktor yang menentukan hasil belajar. Hasil belajar dipengaruhi oleh berbagai faktor, baik faktor dari dalam (internal) maupun faktor dari luar (eksternal).

Menurut Suryabrata dalam Marselina (2007): yang termasuk faktor internal adalah faktor fisiologis dan psikologis (misalnya kecerdasan motivasi berprestasi dan kemampuan kognitif), sedangkan yang termasuk faktor eksternal adalah faktor lingkungan dan instrumental (misalnya guru, kurikulum dan model pembelajaran). Dari beberapa pendapat tersebut dapat diambil kesimpulan bahwa hasil belajar merupakan taraf kemampuan siswa yang berupa nilai atau prestasi yang diperoleh dari proses belajar baik berupa pengetahuan maupun keterampilan. Hasil belajar juga dipengaruhi oleh faktor-faktor yang menentukan bagaimana hasil belajar siswa dalam suatu pembelajaran. Hasil belajar yang akan diteliti nilai atau prestasi dari ranah kognitif atau pengetahuan karena dapat mengetahui seberapa besar materi yang 
ditangkap oleh siswa selama proses pembelajaran.

\section{METODE}

Penelitian ini merupakan penelitian tindakan kelas, peneliti berinteraksi langsung dengan subjek di lapangan. Adapun yang diteliti yaitu aktivitas belajar (memperhatikan, membaca buku, bertanya, mengerjakan latihan dan menulis intisari) dan hasil belajar siswa pada mata pelajaran biologi. Selanjutnya dalam penelitian ini diperoleh data-data kualitatif dalam bentuk uraian dan data kuantitatif yang merupakan hasil belajar siswa yang diperoleh melalui tes yang dapat dianalisis secara deskriptif. Penelitian ini dilaksanakan di kelas XI IPA ${ }_{1}$ SMA Muhammadiyah 1 Metro dengan jumlah siswa 38 siswa. Penelitian ini dilakukan dalam dua siklus, tiap siklus tiga kali pertemuan. Adapun strategi yang digunakan pada penelitian adalah penerapan strategi pembelajaran PQ4R dalam belajar biologi pada materi Sistem Ekskresi dan Sistem Koordinasi Manusia (Sistem Saraf dan Hormon).

Dalam penelitian tindakan kelas ini ada beberapa faktor yang diteliti. Faktorfaktor tersebut adalah: 1) aktivitas, adapun aktivitas yang akan diteliti meliputi memperhatikan penjelasan guru, membaca buku, bertanya, mengerjakan latihan, dan menulis intisari. 2) Hasil belajar merupakan derajat penguasaan materi yang diambil setiap akhir siklus, berupa skor dari hasil tes. Alat untuk mengumpulkan data tentang aktivitas siswa, peneliti menggunakan wawancara dan lembar observasi aktivitas sedangkan untuk mendapatkan data tentang hasil belajar menggunakan tes.

Indikator keberhasilan dalam indikator ini adalah: persentase ketercapaian indikator aktivitas siswa meningkat dan setiap siklusnya.
Indikator aktivitas belajar siswa yang nampak dalam pembelajaran dengan strategi pembelajaran PQ4R adalah: a) Memperhatikan pembelajaran guræ $70 \%$, yaitu perhatian dan pandangan ke arah guru serta tidak melakukan aktivitas lainnya seperti memainkan handphone, mengobrol dengan teman. b) Membaca buku $\geq 70 \%$, yaitu membaca buku sesuai materi dengan pandangan sepenuhnya ke arah buku dengan menunjukkan tulisan pada kalimat-kalimat yang dibaca dalam buku. c) Bertanya $\geq 20 \%$, setelah masing-masing siswa membaca buku panduan materi maka siswa dapat mengungkapkan pertanyaan sesuai dari materi yang mereka baca. d) Mengerjakan latihaæ $75 \%$, yaitu mengerjakan tugas yang diberikan oleh guru. e) Menulis intisaßિ 70\% , mencatat semua jawaban dari pertanyaan yang telah dibuatnya sendiri berupa catatan-catatan singkat yang mudah dipahami bagi siswa itu sendiri. Hasil belajar siswa meningkat dari setiap siklusnya. Peningkatan hasil belajar dikatakan berhasil jika pada tes akhir siklus pada siklus kedua, $70 \%$ siswa telah memperoleh nilai tes $\geq 72$.

\section{HASIL}

Dalam penelitian ini terdapat dua jenis data yaitu aktivitas belajar siswa yang diisi oleh observer dengan lembar observer dan data hasil belajar yang diperoleh dari nilai hasil tes evaluasi dari setiap siklus.

\section{Deskripsi Data Aktivitas Belajar Siswa Siklus Idan II.}

Dalam penelitian ini aktivitas belajar siswa diperoleh dari hasil pengamatan yang dilakukan pada setiap pertemuan. Adapun indikator yang diamati dalam aktivitas belajar siswa antara lain memperhatikan penjelasan guru, membaca buku, bertanya, mengerjakan latihan, dan menulis 
intisari. Aktivitas siswa dalam setiap pertemuan diamati dengan menggunakan lembar observasi yang diisi oleh observer. Aktivitas siswa dalam siklus I dan dimasukkan data dalam lembar observer setiap pertemuan selama $3 \mathrm{kali}$ pertemuan. Deskripsi data aktivitas belajar siswa hasil observasi siklus I dan II dapat dilihat pada Tabel 1.

Berdasarkan tabel 1 dapat dilihat indikator aktivitas keterlibatan belajar mengalami peningkatan dari siklus I ke siklus II. Aktivitas belajar siswa dalam proses pembelajaran sudah memenuhi target yang ingin dicapai. Berdasarkan data di atas dapat ditarik kesimpulan adanya perkembangan aktivitas yang dilakukan siswa pada tiap-tiap siklusnya. Indikator aktivitas belajar siswa yang diamati yaitu memperhatikan penjelasan guru, membaca buku, bertanya, mengerjakan latihan, membuat intisari.

\section{Deskripsi Data Hasil Belajar Siswa} Siklus I dan II.

Peningkatan hasil belajar siswa siklus Idan II dapat dilihat pada tabel 2.
Berdasarkan Tabel 2 menunjukkan bahwa ketuntasan belajar pada siklus I, mengalami penurunan secara drastis dari prasurvei sebesar 33,15\%. Pada saat pra survei diperoleh 46,15\% siswa yang tuntas dengan nilai terendah 50 dan nilai tertinggi adalah 78. Kemudian menjadi $13 \%$ dengan nilai terendah adalah 44 dan nilai tertinggi 72 pada siklus I. Namun persentase siswa yang tuntas belum mencapai target yang diinginkan yaitu > $70 \%$.

Ketuntasan belajar pada siklus II mengalami peningkatan dari siklus I sebesar 57,85\%. Pada siklus II diperoleh $71 \%$ siswa yang tuntas dengan nilai terendah adalah 60 dan nilai tertinggi adalah 88. Untuk skor rata-rata hasil belajar juga mengalami peningkatan yaitu $56,97 \%$ pada siklus I menjadi 72,95\% pada siklus II. Pada siklus II tersebut indikator ketercapaian yang diharapkan yaitu $>70 \%$ dan pada siklus II ini ketuntasan balajar mencapai $71 \%$. Sehingga dapat disimpulkan bahwa target ketuntasan belajar telah tercapai.

Tabel 1 Persentase Indikator Aktivitas yang Dilakukan Siswa dalam Proses Pembelajaran Siklus I, II.

\begin{tabular}{|c|l|c|c|c|c|}
\hline No & \multicolumn{1}{|c|}{ Indikator Aktivitas } & Target & $\begin{array}{c}\text { Siklus I } \\
\mathbf{( \% )}\end{array}$ & $\begin{array}{c}\text { Siklus II } \\
\mathbf{( \% )}\end{array}$ & Ket. \\
\hline 1 & Memperhatikan Penjelasan Guru & $\geq 70 \%$ & $65,7 \%$ & $87,7 \%$ & $\mathrm{~T}$ \\
2 & Membaca Buku & $\geq 70 \%$ & $82,4 \%$ & $81,5 \%$ & $\mathrm{~T}$ \\
3 & Bertanya & $\geq 20 \%$ & $11,3 \%$ & $21 \%$ & $\mathrm{~T}$ \\
4 & Mengerjakan Latihan & $\geq 75 \%$ & $80,6 \%$ & $86,4 \%$ & $\mathrm{~T}$ \\
5 & Membuat Intisari & $\geq 70 \%$ & $80,6 \%$ & $86,4 \%$ & $\mathrm{~T}$ \\
\hline
\end{tabular}

Keterangan:

T : Tercapai

BT : Belum Tercapai

Tabel 2 Data Hasil Belajar Siswa Siklus Idan II.

\begin{tabular}{|c|c|l|c|c|c|c|c|}
\hline \multirow{2}{*}{ No } & \multirow{2}{*}{ Nilai } & \multirow{2}{*}{ Komponen Analisis } & \multicolumn{2}{|c|}{ Jumlah Siswa } & \multicolumn{4}{|c|}{ \% hasil belajar } \\
\cline { 4 - 8 } & & & \multicolumn{2}{|c|}{ Siklus } & \multicolumn{3}{|c|}{ Siklus } \\
\cline { 4 - 8 } & & I & II & Pra PTK & Siklus I & Siklus II \\
\hline 1 & $\geq 72$ & Tuntas Belajar & 5 & 27 & 46.15 & 13,15 & 71 \\
\hline 2 & $<72$ & Tidak Tuntas Belajar & 33 & 11 & 53.85 & 86,5 & 29 \\
\hline & & & & & & & \\
\hline
\end{tabular}




\section{PEMBAHASAN}

Berdasarkan data yang diperoleh dari hasil penelitian dapat diketahui bahwa penerapan strategi pembelajaran PQ4R (Preview, Question, Read, Reflect, Recite and Review) dapat meningkatkan aktivitas dan hasil belajar. Fakta tersebut menunjukkan adanya peningkatan aktivitas dan hasil belajar siswa pada materi Sistem Ekskresi dan Sistem Koordinasi Manusia (Sistem Saraf dan Hormon). Ternyata aktivitas yang terjadi di kelas dapat mempengaruhi hasil belajar siswa. Ini ditunjukkan dari hasil belajar siklus II meningkat dari hasil belajar siklus I dan pra-PTK.

\section{Aktivitas Belajar Siswa}

Dalam belajar sangat diperlukan adanya aktivitas, tanpa aktivitas belajar itu tidak mungkin akan berlangsung dengan baik. Peningkatan aktivitas belajar dapat memberikan peningkatan terhadap motivasi untuk belajar. Dengan membiasakan siswa melakukan aktivitas yang menunjang dalam belajar siswa maka peran guru akan lebih memiliki makna dalam pembelajaran.

\section{a. Memperhatikan Penjelasan Guru}

Pada pertemuan pertama siklus I, selama dalam pembelajaran siswa yang melakukan aktivitas belajar memperhatikan penjelasan guru dengan persentase $60,5 \%$. Dalam pembelajaran hal ini dilihat masih kurang karena siswa tidak fokus dalam memperhatikan apa yang sedang guru jelaskan. Banyak siswa yang masih mengobrol dengan teman sebangkunya, dan terdapat siswa bertanya kepada observer yang sedang mengamati proses pembelajaran, hal ini dilihat dari kegiatan aktivitas siswa yang dilakukan. Pada pertemuan kedua terjadi penurunan aktivitas memperhatikan penjelasan guru menjadi $57,8 \%$, hal ini dilihat dengan banyaknya siswa yang tidak memperhatikan penjelasan guru.
Hal ini dikarenakan kurangnya motivasi yang dimiliki siswa untuk belajar. Pada pertemuan ketiga terjadi peningkatan aktivitas siswa yang dilakukan menjadi 78,9\%, hal ini dilihat banyaknya siswa yang sudah memperhatikan penjelasan peneliti lakukan dalam pembelajaran.

Dalam siklus II pertemuan pertama terdapat siswa yang melakukan aktivitas sebanyak 92,1\%, sedangkan pada pertemuan kedua mengalami penurunan menjadi $84,2 \%$ dan terdapat penurunan sebesar 7,9\%. Pada pertemuan ketiga mengalami peningkatan sebesar 2,6 menjadi $86,8 \%$. Pada siklus I terdapat peningkatan dan penurunan aktivitas siswa dalam memperhatikan penjelasan guru. Pada aktivitas ini mengalami peningkatan dan penurunan setiap pertemuannya. Peningkatan aktivitas memperhatikan penjelasan guru dari siklus I ke siklus II dengan rata-rata dari setiap siklus $65,7 \%$ dan 87,7\%, peningkatan aktivitas ini 22\%. Hal ini dikarenakan siswa sudah mulai termotivasi dan bersungguh-sungguh untuk belajar.

Kegiatan ini sesuai dengan pendapat Sardiman dalam Arief (2008:6) yang menyatakan "dalam belajar sangat diperlukan adanya aktivitas, tanpa aktivitas belajar itu tidak mungkin akan berlangsung dengan baik. Aktivitas dalam proses belajar mengajar merupakan rangkaian kegiatan yang meliputi keaktifan siswa dalam mengikuti pelajaran, bertanya hal yang belum jelas, mencatat, mendengarkan, berpikir, membaca dan segala kegiatan yang dilakukan yang dapat menunjang prestasi belajar”. Hal ini juga sesuai dengan penelitian Arief (2008) bahwa mendengarkan penjelasan guru pada strategi pembelajaran PQ4R ini dapat meningkatkan aktivitas belajar siswa, sehingga mengakibatkan perubahan pada diri siswa. 
b. Membaca Buku

Pertemuan pertama dalam pembelajaran yang dilakukan menggunakan strategi pembelajaran PQ4R oleh siswa kelas XI IPA A $_{1}$ akan dilihat yaitu aktivitas membaca buku. Dalam aktivitas membaca buku pada pertemuan pertama siklus I terdapat aktivitas siswa yang melakukan ini sebesar 73,6\%. Hal ini merupakan kegiatan awal yang cukup baik, karena hanya 26,4\% siswa yang tidak melakukan kegiatan membaca buku. Pertemuan kedua terdapat peningkatan hasil pengamatan sebesar $84,2 \%$ dari pertemuan pertama sebesar $10,6 \%$. Pada pertemuan ketiga mengalami peningkatan sebesar 5,2\% menjadi 89,4\%. Sedangkan pada pertemuan pertama siklus II siswa yang melakukan aktivitas membaca buku sebesar 76,3\%, pertemuan kedua mengalami peningkatan menjadi $78,9 \%$ dan pertemuan ketiga peningkatan aktivitas sebesar 10,5\% menjadi 89,4\%. Pada aktivitas ini siswa sudah mulai mengerti pentingnya membaca buku pelajaran. Hasil dari aktivitas pada siklus II sudah melebihi target yang ingin dicapai yaitu $\geq 70 \%$.

Menurut Trianto (2009:151-153) menyatakan Read, membaca bahan bacaan secara aktif, yakni dengan cara pikiran siswa harus memberikan reaksi terhadap apa yang dibacanya. Hal ini berlaku karena membaca buku dapat meningkatkan aktivitas belajar siswa dengan mengandalkan daya ingat siswa. Pada penelitian Arief (2008) menyatakan bahwa membaca buku juga dapat meningkatkan aktivitas belajar siswa, terdapat peningkatan aktivitas belajar siswa dalam penelitiannya tersebut.

\section{c. Bertanya}

Pada pertemuan pertama siklus I aktivitas siswa bertanya sebesar 10,5\%, hal ini merupakan rasa keingintahuan siswa terhadap suatu permasalahan yang masih kurang. Pada pertemuan pertama siswa yang bertanya terdapat $10,8 \%$ atau berjumlah 4 siswa dari sebanyak 38 siswa. Pada pertemuan kedua terdapat penurunan siswa yang bertanya menjadi $7,8 \%$ yaitu hanya 3 siswa yang bertanya. Pada pertemuan ketiga terdapat peningkatan sebesar $7,9 \%$ menjadi 15,7\%. Hal ini terlihat sudah banyak siswa yang timbul rasa percaya diri dan keingintahuan dalam suatu permasalahan yang tidak mereka ketahui. Dalam pertemuan pertama siklus II terdapat siswa yang bertanya sebesar $18,4 \%$, pada pertemuan kedua tidak mengalami peningkatan masih seperti pada pertemuan pertama yaitu 18,4\%. Pada pertemuan ketiga mengalami peningkatan menjadi 26,3\%, peningkatan aktivitas ini sebesar 7,9\%. Pada aktivitas ini sudah banyak siswa yang bertanya, walaupun masih terdapat siswa yang pada pertemuan sebelumnya sudah berani untuk bertanya. Hal ini karena sudah mulai timbul rasa keingintahuan yang besar dari siswa tersebut agar lebih mengetahui permasalahan yang tidak mereka ketahui, dan minat belajar yang dimiliki siswa.

Hal ini berlaku sesuai dengan pendapat Sardiman (2011:101) "macammacam aktivitas siswa yaitu Visual activities, seperti: membaca, memperhatikan gambar, demonstrasi percobaan dan lainnya, Oral activities, seperti: menyatakan, merumuskan, bertanya, memberi saran, mengemukakan pendapat dan sebagainya, Listening activities, seperti: menggambar, mendengarkan, percakapan diskusi, pidato dan music dan Mental activities, seperti: mengungkap, mengingat, memecahkan soal, menganalisa, dan sebagainya”. Keingintahuan siswa yang diungkapkan melalui pertanyaan atau aktivitas 
bertanya akan menghasilkan konsepkonsep pemahaman serta akan tersusun secara terstruktur dalam pengalaman belajar siswa dan pada akhirnya akan menghasilkan pengetahuan baru pada siswa. Dalam pembelajaran terkadang aktivitas bertanya akan mengalami peningkatan terkadang penurunan aktivitas bertanya.

\section{d. Mengerjakan Latihan}

Pertemuan pertama siklus I terdapat $86,8 \%$ siswa yang mengerjakan latihan, pada pertemuan kedua mengalami penurunan sebesar $10,5 \%$ menjadi 76,3\%. Hal ini karena kurangnya minat siswa dalam mengerjakan latihan, karena mereka berpikir latihan ini tidak mempengaruhi nilai mereka nantinya. Pada pertemuan ketiga mengalami peningkatan menjadi $78,9 \%$, pada pertemuan ini siswa yang mengerjakan latihan tidak seperti pada pertemuan pertama, akan tetapi minat siswa untuk mengerjakan latihan sudah ada. Pada siklus II pertemuan pertama siswa yang mengerjakan latihan terdapat sebesar $78,9 \%$ serta mengalami peningkatan pada pertemuan selanjutnya, pada pertemuan kedua siswa yang mengerjakan latihan sebesar 89,4\%, dan pada pertemuan ketiga menjadi 92,1\%, peningkatan aktivitas mengerjakan latihan sebesar $2,7 \%$. Hal ini sudah melebihi target yang diinginkan, dan siswa yang mengerjakan latihan sudah hampir seluruhnya mengerjakan latihan yang diberikan oleh guru.

Hal ini sesuai dengan pendapat Sardiman (2011:101) yang menyatakan "macam-macam aktivitas siswa yang menunjang aktivitas siswa salah satunya yaitu Motor activities, seperti: mengungkap, mengingat, memecahkan soal, mereparasi, berkebun, memelihara binatang dan lain-lain”. Aktivitas ini juga dapat meningkatkan aktivitas belajar siswa yang dilakukan oleh Arief (2008) pada siswa kelas XI SMA MAN 1 Metro.

\section{e. Membuat Intisari}

Pertemuan pertama siklus I terdapat $86,8 \%$ siswa yang membuat intisari dari pertemuan yang dilakukan. Pada pertemuan kedua mengalami penurunan sebesar 10,5\% menjadi 76,3\%. Pada pertemuan ketiga siswa yang membuat intisari masih seperti mengalami peningkatan menjadi $78,9 \%$. Pada siklus II pertemuan pertama siswa yang membuat intisari terdapat 78,9\% siswa yang membuat intisari, pada pertemuan kedua mengalami peningkatan menjadi 89,4\%. Sedangkan pada pertemuan ketiga mengalami peningkatan menjadi 92,1\%. Peningkatan aktivitas membuat intisari sebesar 2,7\%, karena siswa sudah mulai termotivasi untuk membuat suatu ringkasan dari pembelajaran yang telah dilakukan.

Peningkatan aktivitas ini sesuai dengan pendapat Trianto (2009:151-153) menyatakan "langkah-langkah yang harus dilakukan dalam strategi pembelajaran PQ4R adalah sebagai berikut: Preview, siswa membaca selintas dengan cepat sebelum mulai membaca bahan bacaan siswa yang memuat tentang materi. Question, siswa mengajukan pertanyan-pertanyaan kepada diri sendiri yang ada pada bahan bacaan. Read, membaca bahan bacaan secara aktif, yakni dengan cara pikiran siswa harus memberikan reaksi terhadap apa yang dibacanya. Reflect, selama membaca siswa tidak cukup menghafal dan mengingat, tetapi mencoba untuk memahami informasi yang ada. Recite, siswa diminta untuk mengingat kembali informasi yang telah dipelajari. Review, meminta siswa membaca intisari yang telah dibuatnya, mengulang kembali seluruh isi bacaan”. Kegiatan aktivitas 
membuat intisari yang dilakukan termasuk kedalam aktivitas PQ4R yaitu Review yang dimana siswa diminta untuk membuat intisari dan membacakan intisari yang telah dibuatnya. Akan tetapi pada penelitian yang dilakukan Arief (2008) membuat intisari terlihat jelas penurunan aktivitas dari siklus I ke siklus II yaitu dari 97,7\% menjadi 91,2\% dengan penurunan persentase 6,5\%.

\section{Hasi Belajar}

Berdasarkan hasil belajar Pra-PTK ke siklus II dapat dilihat pada (tabel 9, halaman 55) hasil belajar Pra-PTK siswa yang mendapat nilai sesuai dengan KKM $\geq 72$ sebesar 46,15\%, sedangkan pada siklus I siswa yang mendapat nilai sesuai dengan $\mathrm{KKM} \geq 72$ menurun menjadi 13,15\% dan pada siklus II jumlah siswa yang mendapat nilai sesuai dengan KKM $\geq 72$ meningkat menjadi $71 \%$. Pada siklus I yang mengalami penurunan dari Pra-PTK yang menjadi $13,15 \%$, hal ini dikarenakan kurangnya siswa belajar saat evaluasi berlangsung, pada hari tersebut 3 mata pelajaran yang mengadakan evaluasi belajar, sehingga pikiran siswa terbagi-bagi antara pelajaran yang lainnya. Akan tetapi pada siklus II, mengalami peningkatan hasil belajar yang cukup memuaskan yaitu $71 \%$, karena siswa sudah bisa lebih fokus dan pikiran siswa tidak terbagibagi lagi, sehingga siswa lebih maksimal belajar untuk tes evaluasi siklus II.

Tingginya nilai rata-rata pada strategi pembelajara PQ4R disebabkan karena pada proses pembelajaran siswa terlibat aktif. Dari proses pembelajaran tersebut siswa mendapatkan pengetahuan tidak hanya dari guru saja akan tetapi dari sumber atau buku yang dimiliki tiap siswa yang berbeda. Pada pembelajaran strategi pembelajaran PQ4R siswa dituntut untuk mengingat apa yang mereka baca dengan kegiatan membaca buku. Ini sesuai dengan pendapat Trianto
(2009:150) strategi PQ4R merupakan salah satu bagian dari strategi elaborasi. Strategi ini digunakan untuk membantu siswa mengingat apa yang mereka baca, dan dapat membantu proses belajar mengajar di kelas yang dilaksanakan dengan kegiatan membaca buku.

Berdasarkan hasil yang telah dicapai selama pelaksanaan pembelajaran dengan mengaplikasikan strategi pembelajaran PQ4R, siswa mengalami peningkatan baik dari segi aktivitas dan hasil belajar pada setiap siklus. Strategi pembelajaran PQ4R dapat mendukung peningkatan aktivitas belajar siswa dan hasil belajar pelajaran Biologi.

\section{KESIMPULAN DAN SARAN}

\section{A. Kesimpulan}

Berdasarkan penelitian tindakan kelas yang telah dilakukan menggunakan strategi pembelajaran PQ4R (Preview, Question, Read, Reflect, Recite, and Review) kelas XI IPA ${ }_{1}$ SMA Muhammadiyah 1 Metro semester genap Tahun Pelajaran 2011/2012, dapat disimpulkan sebagai berikut: 1) Dapat meningkatkan aktivitas belajar siswa pelajaran biologi kelas XI IPA $_{1}$ SMA Muhammadiyah 1 Metro. Dengan peningkatan aktivitas belajar siswa yaitu memperhatikan penjelasan guru sebesar $65,7 \%$ menjadi $87,7 \%$, membaca buku sebesar $82,4 \%$ mengalami penurunan menjadi $81,5 \%$, bertanya sebesar $11,3 \%$ menjadi 21\%, mengerjakan latihan sebesar $78 \%$ menjadi $84,2 \%$ dan membuat intisari sebesar $73,6 \%$ menjadi $75,4 \%$. 2) Dapat meningkatkan hasil belajar siswa pelajaran biologi kelas XI IPA $_{1}$ SMA Muhammadiyah 1 Metro, dengan peningkatan yang terjadi pada siklus I ke siklus II dari 13\% menjadi $71 \%$ dan telah mencapai $\mathrm{KKM} \geq 72$. 


\section{B. Saran}

Untuk turut serta dalam menyumbangkan pemikiran guna meningkatkan hasil belajar siswa, maka disampaikan saran-saran sebagai berikut: 1) Bagi siswa: siswa hendaknya lebih banyak membaca buku agar lebih menambah pengetahuan yang ada dan lebih aktif lagi dalam proses pembelajaran, siswa hendaknya memiliki buku tidak hanya 1 buku saja yang dapat digunakan sebagai referensi dalam pelajaran biologi, siswa hendaknya lebih percaya diri dalam mengungkapan pendapat dan bertanya apabila masih ada yang kurang dipahaminya. 2) Bagi guru: guru dapat mengaplikasikan strtaegi pembelajaran PQ4R dalam pelajaran biologi sebagai strategi pembelajaran alternativ karena strategi ini mengutamakan ingatan siswa dengan membaca buku. Guru diharapkan lebih mengajak siswa untuk rajin membaca buku agar siswa dapat mengikuti proses pembelajaran dengan baik dan lebih berperan aktif dalam proses pembelajaran.

\section{DAFTAR RUJUKAN}

Ahmadi, Abu. 2001. Didaktik Metodik. Semarang: C.V. Toha

Al-Shihab. 2010. Penerapan Strategi PQ4R. (Online)

http://alsyihab.blogspot.com /2010/10/penerapan-strategi-pq4rpreview.html. Diakses pada tanggal 30 Mei 2010. Pukul 20:00 WIB

Arief, Fathoni. 2008. Upaya Peninkatan Aktivitas dan Hasil Belajar Biologi Dengan Menggunakan Strategi Pembelajaran PQ4R (Preview, Question, Read, Reflect, Recite, and Review) Pada Siswa Kelas XI IPA MAN 1 Metro Tahun Pelajaran 2009/2009. Skripsi tidak diterbitkan. Metro: Universitas Muhammadiyah Metro

Marselina: 2007. Kesuksesan dalam Mencapai Prestasi Belajar. (Online) http//www.marselina.co.cc.

Diakses 14 Oktober 2011 Pukul 20.00

Sardiman. 2011. Interaksi dan Motivasi Belajar Mengajar. Jakarta: Raja Grafindo Persada

Riyanto, Yatim. 2010. Paradigma Baru Pembelajaran. Jakarta: Kencana

Trianto. 2009. Model-Model Pembelajaran Inovativ Berorientasi Konstruktif. Jakarta: Prestasi Pustaka 